Studia i Materiały, 2013 (16): 123-134

\title{
Ogłoszenie jako reklama na przykładzie węgierskich internetowych ofert pracy ${ }^{1}$
}

\begin{abstract}
Agata Keller*
Wspótcześnie reklama jest zjawiskiem niemal wszechobecnym. Rozwój Internetu poszerzyt wachlarz możliwości jej występowania. Niniejszy artykut ma na celu wykazać, że oferty pracy dostępne online, tak bardzo upodabniaja się do reklamy, że można je z nia utożsamiać. Chodzi nie tylko o podobieństwa formalne, w postaci użytych środków perswazji językowej i pozajęzykowej, lecz także zbieżność celów przyświecających reklamie i badanym ogtoszeniom, tj. zachęcanie do podjęcia konkretnego działania, wzbudzenie zainteresowania marka i budowanie pozytywnych z nia skojarzeń. Artykut powstat w oparciu o zbiór ogtoszeń zamieszczonych na przestrzeni trzech tygodni z przetomu maja i czerwca 2013 na stronach wegierskojęzycznego serwisu poświęconego szukaniu zatrudnienia. Spośród zebranych ofert (1801), niewiele ponad dwie trzecie zredagowano w jezyku wegierskim (1211 ogtoszeń). Większość ofert obcojęzycznych byta po angielsku (590). Nie wzięto ich pod uwage w analizie oprócz ostatniej jej cześsi, poświęconej wizualnej stronie ogtoszeń. Prawie dwie trzecie wszystkich ofert (1119) zostato zamieszczonych przez firmy rekrutacyjne. Wszystkie ttumaczenia wykonata autorka.
\end{abstract}

Słowa kluczowe: e-reklama, internetowe oferty pracy, outsourcing, język marketingu.

Nadesłany: 16.09.2013 | Zaakceptowany do druku: 25.11.2013

\section{Announcement as an advertisement on the example of Hungarian Internet job offers}

Nowadays the advertisements are almost ubiquitous. Developement of the Internet opened way for new possibilities in advertising. In this article I tried to show that the online job offers are virtually commercials. It is visibile not only in applied linguistic and supralinguistic ways of persuasion but also in the identical goals of both the advertisements and the featured announcement, i.e. encouraging the readers to take specific actions, making the brand more popular and creating its positive image. The article was written on a basis of 1801 announcements published within three weeks at the turn of May and June 2013 on one of the Hungarian recruitment sites. Slightly over two-thirds of all the material was in Hungarian (1211 items). Most of the foreign language offers (590) was in English and I analyse them only in the paragraph about the advertisements' visual side. Almost two-thirds (1119) of all of the offers were published by HR companies. The translations are all of my authorship.

Keywords: online advertising, internet job offers, outsourcing, marketing language.

Submitted: 16.09.2013 | Accepted: 25.11.2013

JEL: M37

\footnotetext{
* Agata Keller - studentka Filologii Ugrofińskiej, Katedra Hungarystyki UW oraz Zarządzania Srodowiskiem, UW.

Adres do korespondencji: ul. Pełczyńskiego 22b m. 47, 01-471 Warszawa; e-mail: akeller@student. uw.edu.pl.
} 


\section{Wstęp}

Reklama jest zjawiskiem złożonym, trudnym do zdefiniowania i stanowiącym przedmiot zainteresowania wielu dziedzin nauki. Posługuje się specyficznym sposobem komunikacji ze względu na swoją wysoką funkcjonalność i maksymalną kondensację treści. Cały komunikat podporządkowany jest nadrzędnemu celowi reklamy: perswazji. Czynnik perswazyjny realizuje się głównie poprzez język, a aby przekaz reklamowy był czytelny, nadawca posługuje się specjalną konwencją, która nie powinna być odbiorcy obca (Skowronek, 2001, s. 7-9). Właśnie ta szczególna forma komunikacji, obok faktu odpłatności, zrównuje ogłoszenia o pracę z reklamami, co starano się wykazać.

$\mathrm{Na}$ początku artykułu zaprezentowano w dużym skrócie pojęcie reklamy i jej pozycję wobec ogłoszenia oraz specyfikę reklamy internetowej i rekrutacji przez Internet. Następnie na podstawie danych liczbowych i cytatów omówione zostały ogólne cechy badanych ogłoszeń, po czym rozpoczyna się główna część artykułu, poświęcona analizie narzędzi perswazji.

Dokonany tu podział na językowe (gramatyka, leksyka, stylistyka, pragmatyka, slogan) oraz pozajęzykowe środki perswazji (marketing, odwołania do świata spoza ogłoszenia, oprawa graficzna) został zaczerpnięty z pracy Marioli Wołk pt. Ogtoszenie czy reklama? Problem definiowania pojęcia ogtoszenie.

\section{Reklama}

P. Lewiński (1999, s. 23), powołując sie na pracę M. Gołki (1994, s. 13), definiuje reklamę jako „każdy płatny sposób nieosobistego prezentowania i popierania zakupu towarów (usług, idei) za pomocą określonych środków, w określonych ramach prawnych i w określonych warunkach wraz z podaniem informacji o samych towarach, ich zaletach, ewentualnie cenie, miejscach i możliwościach realizacji zakupu". Istotna jest dwoistość reklamy: jej informacyjny, a zarazem perswazyjny charakter. Jedna z publikacji J. Bralczyka nosi nawet tytu „Reklama - perswazja informacji” (1994).

Ale kto kogo informuje, kto kogo namawia? Reklama, będąc komunikatem masowym, pozbawiona jest konkretnej osoby nadawcy czy odbiorcy. „Ta właściwość pozwala zawęzić termin reklama do specjalnie przygotowywanych na czyjeś zlecenie komunikatów skierowanych do powszechnego odbiorcy" (Lewiński, 1999, s. 24). Według W. Lubasia (2006, s. 143) reklama medialna posiada kilkoro nadawców:

1) ukrytego inicjatora i twórcę tekstów (pracownicy przedsiębiorstwa) ${ }^{2}$,

2) ujawnionego i nazwanego na poziomie komunikacyjnym (przedsiębiorstwo),

3 ) wspomagającego na poziomie komunikacyjnym poprzez kanał (portal internetowy).

Niezależnie od tego, kogo nazwiemy nadawcą komunikatu, nie zmieni to charakteru samej reklamy, który według P. Lewińskiego (1999, s. 24) jest:

- komercyjny: za jej wykonanie i upowszechnianie płaci się, licząc na przyszłe zyski z inwestycji;

- teleologiczny: nastawienie na realizację założonych celów - illokucyjncgo i perlokucyjnego;

- jednostronny: odbiorca nie ma możliwości odpowiedzieć nadawcy;

- publiczny: nadawca jest anonimowy;

- multimedialny: przekaz jest wielokanałowy oraz wielokodowy.

\subsection{Reklama a ogłoszenie}

Granica semantyczna między ogłoszeniem a reklamą jest mało wyraźna. Wątpliwości związane z eksplikacją obu terminów prezentuje M. Wołk (2001) i dochodzi do wniosku, że choć niektóre ogłoszenia stosują perswazję, podstawową technikę reklamy, to jednak nie sposób nazywać ich reklamami. Zgadzam się z wnioskami badaczki, jednak od przeprowadzenia tamtego badania minęła już ponad dekada, ponadto dotyczyło ono drobnych ogłoszeń prasowych, czyli bardzo krótkich, często jednozdaniowych anonsów po polsku zamieszczonych na łamach lokalnego dziennika. Owe teksty różnią się zatem od tych stanowiących podstawę niniejszego artykułu językiem, formą, treścią, zasięgiem, osobą nadawcy i czasem powstania.

Literatura marketingowa uznaje oferty pracy za rodzaj reklamy (Abrahams i in., 2013, s. 2788; Lewiński, 1999, s. 27; Ngai, 2003, s. 236). R. Zusman i R. Landis w swoim artykule (2002, s. 286) zwracaja uwagę, że dostrzeżenie podobieństw między reklamami produktów a ogłoszeniami o pracę nie jest nowym pomysłem. Powołu- 
jąc się na publikacje S. Rynes (1991) ${ }^{3}$ oraz B. Hodesa (1982), podkreślają, że ,podstawowe procesy rekrutacji $\mathrm{w}$ organizacji mają wiele wspólnego z reklamą konsumencką, ponieważ oferty rekrutacyjne mają po pierwsze przyciągnąć i utrzymać uwagę przyszłych kandydatów i kandydatek, a po drugie popychać do konkretnego działania (tzn. do wysłania zgłoszenia)" (Zusman i Landis 2002, s. 289).

Postulują, że sukces komunikatu zależy od wywołania pozytywnego wrażenia, a aby to osiągnąć, należy: (1) przyciągnąć uwagę, (2) wzbudzić zainteresowanie, (3) zyskać aprobatę, (4) wywołać pozytywne skojarzenia, (5) skłonić do działania (Zusman i Landis, 2002, s. 290). Podobne zadania wyznacza się reklamie, według różnych teorii są to: SLB (stay, look, buy), AIDA (attention, interest, desire, action), AIDCAS (attention, interest, desire, conviction, action, satisfaction), DIPADA (definition, identification, proof, acceptance, desire, action) (Lewiński, 1999, s. 26).

\subsection{Reklama w Sieci}

Można powiedzieć, że podstawowym elementem reklamy jest slogan (Bralczyk 2004, s. 124). I choć wielokrotnie będzie o nim mowa w dalszej części tekstu, to nie we wszystkich ogłoszeniach o pracę jest obecny. W reklamie internetowej większe znaczenie od sloganu zyskują: tekst właściwy (body copy albo copy), nagłówek (header, heading albo head) i układ graficzny (layout, tzn. kompozycja, kolorystyka, czcionki itp.) czy ewentualne ilustracje (images albo visual) (Stokes, 2008, s. 222-233).

Powołując się na publikację J. Price'a i L. Price, R. Stokes (2008, s. 223) zauważa, że rozwój Internetu doprowadził do powstania „publiczności jednego/jednej” (audience of one). Oznacza to, że w Sieci istnieje wiele nisz i związanych $\mathrm{z}$ nimi publiczności, przyzwyczajonych do tego, by zwracać się do nich w bardzo indywidualny sposób. Aby odnieść sukces komunikacyjny w takiej sytuacji, należy trafnie określić grono odbiorców i posługiwać się językiem, który do nich dotrze. Należy również pamiętać o ogromnej dynamice zmian językowych zachodzących w Internecie i umiejętnie je wykorzystywać (Stokes, 2008, s. 233).

\section{Rekrutacja przez Internet}

Internet przyczynił się (Rybiński, 2007, s. 67-72) do rozwoju outsourcingu, czyli „przesunięcia zamówień, produkcji lub usług do innej firmy" oraz offshoringu, czyli „przesunięcia zamówień, produkcji lub usług poza granice kraju" (Rybiński, 2007, s. 14). Motywacje do podjecia takich kroków są różne, ale na pierwszy plan wysuwaja się: chęć zdobycia nowych klientów bądź lepsza obsługa obecnych, redukcja kosztów i zwiększenie wydajności (Rybiński, 2007, s. 63).

Regionami specjalizującymi się w eksporcie usług są Daleki Wschód (Indie, Chiny, Azja Południowo-Wschodnia) i państwa Grupy Wyszehradzkiej (ich udział wzrósł szczególnie po wstąpieniu do Unii Europejskiej). Firmy matki korzystające $\mathrm{z}$ offshoringu pochodzą głównie z krajów wysoko rozwiniętych, na naszym kontynencie oznacza to Europę Zachodnia, a zwłaszcza Wielką Brytanie i Niemcy (Rybiński, 2007, s. 87-88). Wielu zachodnim korporacjom opłaca się prowadzenie fabryk czy punktów obsługi klienta na terenie nowych państw członkowskich UE, przede wszystkim: Czech, Polski, Węgier i Słowacji (Rybiński, 2007, s. 43-50). Jednakże offshoring przyczynia się także do wzrostu liczby specjalistów różnych dziedzin (głównie inżynierii) i do poprawy infrastruktury w strukturach vendora usług (Rybiński, 2007, s. 59).

Offshoring i outsourcing oprócz call centre i zakładów przemysłowych to również korporacje zajmujące się kompleksową obsługa innych firm (przede wszystkim w zakresie usług IT, księgowości i polityki kadrowej). Naborem pracowników często zajmują się przedsiębiorstwa zewnętrzne. Warto w tym miejscu wspomnieć o nowej dziedzinie marketingu rozwijającej się na pograniczu human resources (HR) i public relations. Chodzi o HR branding, inaczej employer branding, czyli budowanie wizerunku przedsiębiorstwa i jego atrakcyjności jako miejsca pracy.

Rosnąca liczba procesów rekrutacyjnych zachodzi w środowisku internetowym i wiele firm dostrzega, że atrakcyjność ogłoszenia i używalność (usability) powiązanej z nim strony internetowej zwiększa szanse organizacji na sukces przy naborze pracowników (Gregory i in., 2013, s. 1951; Zusman i Landis, 2002, s. 287). 


\section{Zestawienie danych $\mathrm{z}$ portalu źródłowego}

Zgromadzone ogłoszenia pochodzą z węgierskiej strony internetowej Jobline.hu poświęconej rekrutacji pracowników i powiązanej z portalem informacyjnym tygodnika HVG. Aby móc w pełni korzystać ze strony, należy założyć konto w serwisie. Rejestracja jest bezpłatna. Serwis adresowany jest i do osób szukajacych pracy, i do podmiotów poszukujących pracowników:

Jobline.hu - eksperckie rozwiązania w rekrutacji

Jobline.hu oferuje unikatowe na Węgrzech rozwiazania w dziedzinie rekrutacji online.

- Pełny zakres usług typu HR branding

- Indywidualne szablony ogłoszeń

- Dostosowanie ogłoszeń do firmy

- Zapisywalne kryteria wyszukiwania

- Możliwość wprowadzania zmian do ogłoszeń

Niespotykany wcześniej w rekrutacji profesjonalizm z pomocą Jobline.hu.

Podane są też stawki za umieszczenie ogłoszenia (różniące się stopniem personalizacji szablonu i czasu wyświetlania oferty: do wyboru są 2 albo 4 tygodnie), za jego dodatkowe wyróżnienie (kiemelési lehetöségek) oraz za płatny, czasowy dostęp do bazy życiorysów zawodowych zamieszczanych przez użytkowników serwisu.

Zestawiono ze sobą 1801 ofert dostępnych na stronie na przestrzeni trzech tygodni (20.05-10.06.2013). Dwa zjawiska zasługują na uwagę:

- 1119, czyli blisko 2/3 ogłoszeń pochodzi od firm rekrutacyjnych (wliczając $\mathrm{w}$ to oferty zamieszczone pod szyldem Jobline.hu, jako asystenta rekrutacji);

- 590, tj. niemal 1/3 ogłoszeń jest po angielsku (dla porównania - oferty w innych jezzykach: 7 po niemiecku, 1 po francusku i 1 po holendersku); uwzględniono je jedynie w części poświęconej oprawie graficznej.

Wszystkie ogłoszenia sa generowane na podstawie szablonów serwisu Jobline.hu, gdzie w obrębie każdej z kilku kategorii należy wskazać jedną lub więcej cech posady (możliwy wybór wielokrotny). Bodaj najważniejsza w tym podziale jest branża (szakterület). Najwiecej ofert zakwalifikowano do działów „Inżynieria/Technologia” (494) i „IT/Informatyka” (400). Na trzecim miejscu znalazły się „Finanse/Rachunkowość”
(297). Kolejne branże reprezentowane są mniej licznie.

Następne trzy kategorie (doświadczenie zawodowe, wykształcenie, język) wyrażaja oczekiwania stawiane kandydatom. Przeważają oferty skierowane do osób z doświadczeniem od roku do trzech lat (1011) i wykształceniem wyższym licencjakim (1138) bądź magisterskim (1037). Najwięcej ofert ze wskazaniem na język zarówno angielski, jak i niemiecki dotyczyło, podobnie jak wszystkich ofert ogółem - inżynierii i informatyki (odpowiednio: 381 i 246).

Zamieszczone ogłoszenia w większości (888 ofert) dotyczyły Budapesztu.

\section{Krótkie omówienie analizowanych ogłoszeń}

Skąpych treściowo i ubogich graficznie ofert jest niewiele, oto jedna $\mathrm{z}$ nich:

Tłumaczenia ustne, rosyjski

Zadania

- powszednie zadania tłumaczeniowe przy osobie dyrektora naszej firmy.

Oczekiwania

- dobre zdolności komunikacyjne,

- elastyczność

- biegła znajomość rosyjskiego.

Co oferujemy

- konkurencyjne wynagrodzenie.

Miejsce pracy

- Tatabánya.

Jak aplikować

- mailowo, poprzez wysłanie CV ze zdjęciem na adres e-mail (...).

Taki rodzaj ogłoszenia własnego (nie zaś zamówionego u firmy rekrutacyjnej), które dodatkowo pozbawione jest logo czy nazwy pracodawcy, stanowi mniej niż 5\% ogółu ogłoszeń. Dobrze jednak pokazuje, jakie pola trzeba wypełnić przy publikacji ogłoszenia. Ogłoszeniodawca może ten układ zmienić - o ile zdecyduje się na któryś $\mathrm{z}$ droższych pakietów usług Jobline.

Pojawiają się ogłoszenia własne zawierające dane pracodawcy. Zazwyczaj są to dobrze rozpoznawalne marki (Audi, Bosch, Tesco, Vodafone), często jednak i tak rozpoczynają ogłoszenie od przedstawienia się, oczywiście z jak najlepszej strony, np.:

\section{Kariera w Audi (...)}

Ekscytujące i niemonotonne środowisko pracy.

Niezależnie od tego, na jakim etapie kariery Pan/i się znajduje, Audi zapewni Panu/ Pani możliwości rozwoju i dostarczy wyzwań. 
Dzięki ciągłej nauce, modelowi rozwoju opartemu na kompetencjach i regularnej wymianie informacji, każda przez nas zatrudniona osoba ma możliwość osiągnąć własne cele i zrealizować swoje plany. Ekscytujące zadania, młodzieżowa atmosfera miejsca pracy i zaawansowane technicznie otoczenie sprawiają, że Audi Hungaria to miejsce, gdzie pracować przychodzi się z przyjemnością. $(\ldots)$

Czasem zamieszczają w ofercie też slogan reklamowy bądź rekrutacyjny, np.:

Sprzedajemy wszystko od bułki po telewizor plazmowy. Atrakcyjniejsza od naszej oferty towarowej jest tylko nasza oferta zatrudnienia. TESCO - liczy się nawet to, co najmniejsze!

Pozbawione narzędzi marketingowych i reklamowych środków perswazji są natomiast ogłoszenia spółek dbających o wizerunek poważnej instytucji, np. kojarzonych $\mathrm{z}$ wegierskim sektorem publicznym, jak MÁV (koleje państwowe) czy OTP Bank.

Najczęstszym typem ogłoszeń są szablony firm rekrutacyjnych. Wzory te posiadają własna oprawe graficzna i pozwalaja wyróżnić się na tle reszty. Ponadto przy zamieszczaniu oferty można ustalić, jakie pola wypełnić i łatwiej nimi zarządzać. W czasie badania na stronie dostępne były ogłoszenia piętnastu różnych firm rekrutacyjnych. Ich oferty zaopatrzone są w logo i nazwę (często to jeden i ten sam znak graficzny). Niektóre korporacje zamieszczają również swój slogan, po wegiersku albo po angielsku, np.: A munka jövóje („Przyszłość pracy”), Better work, better life („Lepsza praca, lepsze życie"), good to know you (,jak dobrze, że się znamy"), Select - the premium choice („Select - pierwszorzędny wybór”), Career suits you („Z kariera Ci do twarzy”), Human Resources Solutions („Rowiązania HR”). Czasem też firmy rekrutacyjne w obrębie oferty reklamują własne usługi:

Jako wiodący na rynku dostawca usług kadrowych oferujemy zarówno naszym pracownikom, jak i zleceniodawcom pełen zakres rozwiązań HR. Trenkwalder Usługi Pracownicze S.A. dla swojego partnera z branży motoryzacyjnej poszukuje 1 osoby na poniższe stanowisko.

Część ogłoszeń opatrzona jest informacją dotycząca przetwarzania danych osobowych:

Odpowiadając na niniejsze ogłoszenie i przesyłając swoje materiały rekrutacyjne, wyrażam zgodę dla Trenkwalder S.A. na przetwarzanie danych osobowych zawartych w moim życiorysie, na wpisanie ich do bazy danych i na przekazanie ich dalej w wypadku odpowiedniej oferty pracy - przy wcześniejszym wyrażeniu przeze mnie na to zgody. Przyjmuję do wiadomości, że w odpowiedzi na moją pisemną prośbe $\mathrm{w}$ tej sprawie, usunięcie danych $\mathrm{z}$ bazy lub ich zamiana nastapi w ciagu 8 dni od złożenia takiego wniosku. Odpowiedni wniosek musi zostać złożony na piśmie w biurze prowadzacym rejestr danych. Oświadczam, że podane przeze mnie informacje są prawdziwe.

Należy zaznaczyć, że informacja, w tym dane osobowe, posiada ogromną wartość. Dla przedsiębiorstw swojego rodzaju zysk stanowi nie tylko znalezienie idealnego kandydata na dane stanowisko, ale i możliwość gromadzenia danych osobowych z myślą o kolejnym naborze (Gregory i in., 2013, s. 1951). Inna firma rekrutacyjna w każdym ogłoszeniu zamieszcza tekst zachęcający do nawiązania $\mathrm{z}$ nią kontaktu:

Jeżeli chce Pan/i otrzymywać informacje o naszych aktualnych ofertach, to klikając tutaj może Pan/i zapisać się do naszej wewnetrznej bazy danych. (...) W celu uzyskania dalszych informacji zechcą Państwo dzwonić pod poniższy numer telefonu.

\section{Analiza językowych środków perswazji}

\subsection{Gramatyka}

Najbardziej oczywisty chyba czynnik perswazyjny to tryb rozkazujący. Jednak ze wzgledu na swoja zbytnia transparentność (nie lubimy raczej, gdy się nas zbyt nachalnie do czegoś namawia) nie jest stosowany zbyt często (wystąpił w 58 ogłoszeniach), a tam gdzie sie pojawia, nie wystepuje $\mathrm{w}$ roli polecenia, ale raczej polecania czegoś, np.:

Studiujesz na uniwersytecie/w szkole wyższej i chcial/abyś swoją wiedzę teoretyczną przenieść na grunt praktyki? Interesujesz sie HR-em, w tym rekrutacja i selekcja? Chciał/ abyś czas praktyk wypełnić prawdziwą pracą w renomowanej firmie konsultingowej o długiej tradycji?

Zatem nie zwlekaj dłużej! Zgłoś się do zespołu GRAFTON Recruitment SA!

Obok rozkaźników pojawia się tryb przypuszczający. Okazuje się on bardziej popularny od imperatywu (obecny w 81 ofertach). Można to tłumaczyć łatwością, z jaką przenosi nas z marzeń i snów w realny świat - tzn. pozwala płynnie przejść od zdań przy- 
puszczających do orzekających, sugerując prawdopodobieństwo spełnienia naszych pragnień (Pałka, 2006, s. 125-127).

Trzecim wyróżniającym się elementem cytatu sa pytajniki (co ważne użyto ich w ponad 250 ofertach, w tym w sloganie jednego z przedsiębiorstw HR: Horogra akar akadni? Chce (pan/i) dać się ztapać? Chce (pan/i) potknać haczyk?. Określaja one typ zdania, a nie tryb czasownika, jednak często łączą się z rozkazami (jak w przykładzie: pytanie? - rozkaz!). Dzieje się tak być może dlatego, że „pytanie od twierdzenia odróżnia inny stosunek do wyrażanej rzeczywistości, analogicznie jak w kategorii trybu. (...) Pytanie jest obok pozdrowienia podstawowym rozpoczęciem kontaktu językowego z drugą osobą" (Bralczyk, 2004, s. 112), a więc ma również ułatwiać zbliżenie komunikatu medialnego do odbiorcy.

Ale jak należy zwracać się do odbiorcy? Większość ofert unika form jednoznacznie zdradzajacych, jaki stosunek poufałości zachodzi między stronami. W pozostałych przypadkach użycie formy ,per pan/i” (163 oferty) przeważa liczebnie nad formą ,per ty" (78 ofert). Niektóre teksty mieszają oba style, np. jedno $\mathrm{z}$ ogłoszeń w pierwszym akapicie zwraca się do nas „na ty”, a trzy ustępy dalej „na pan/i”:

Dołącz do nas i Ty!

Gdzie się zaczyna historia Pańskiego sukcesu? Niech Pan/i zgłosi się teraz!

Jak widać relacje pomiędzy osobami wyrażane są nie tylko przez orzeczenie, lecz także poprzez zaimki osobowe i sufiksy dzierżawcze (birtokos személyjel). Użycie pierwszej osoby liczby mnogiej podkreśla istnienie społeczności stojącej za korporacją. W ofertach firm HR są to zwroty takie, jak: „nasz partner”; „na rzecz naszej firmy partnerskiej poszukujemy”, „nasz Klient” itd. W ogłoszeniach własnych, podkreśla się dychotomię „my-ty”, jak w cytowanym powyżej: Dotacz do nas i Ty! i poniżej:

Dołącz do nas, ponieważ program ten tworzymy z myślą o Twoim życiu! Rozpocznij swoją karierę z nami, aby zdobywszy rozległe doświadczenie $\mathrm{w}$ wielonarodowym środowisku przygotować się na kierownicze stanowisko!

\subsection{Leksyka}

Gdy znaczenie jakiegoś wyrazu zawiera element emocjonalny lub wartościujący, możemy powiedzieć, że słowo to jest nace- chowane, np. „bachor” to dziecko, o którym nadawca wyraża się z niechęcią (Grzegorczykowa, 1990, s. 58). Większość ogłoszeń używa słów nacechowanych dodatnio, np. w opisie przedsiębiorstwa:

Art1st Design Studio od 20 lat z sukcesami. globalna firma motoryzacyjna, należąca ze swoimi produktami do światowej czołówki.

Często zachęcająco działać mają odwołania (obecne w 452 ogłoszeniach) do zagranicznego charakteru korporacji, np.:

LESAFFRE WEGRY S.A. - numer jeden wśród węgierskich i wschodnioeuropejskich wytwórców i dostawców drożdży, członek wiodącej na rynku, francuskiej grupy kapitałowej Lesaffre poszukuje osób na poniższe stanowisko:...

Partnerem naszym jest stabilne, od lat obecne na węgierskim rynku wielonarodowe przedsiębiorstwo produkcyjne.

Dla międzynarodowej, solidnej firmy partnerskiej poszukujemy.

Niekiedy internacjonalizm podają wprost jako zaletę:

Oferujemy

- wielonarodowe środowisko,

- konkurencyjne wynagrodzenie.

Akcentowanie krajowego rodowodu firmy daje się zauważyć dużo rzadziej (w 57 ofertach).

Atrakcyjność firmy i jej związki z zagranicą podkreśla się również przez stosowanie zwrotów zaczerpniętych z języka angielskiego (Bralczyk, 2004, s. 38; Lubaś, 2006, s. 185-188; Wołk, 2001, s. 158-161). W węgierszczyźnie tendencja do zapożyczeń jest od dawna dużo słabsza niż w Pol$\mathrm{sce}^{4}$. Węgierskie określenia niektórych nowoczesnych urządzeń czy udogodnień okazały się na tyle trafne, że na stałe weszły do jezyka powszechnego, np. táblagép (tablet), honlap (strona główna), okostelefon (smartfon) czy számítógép (komputer). Jednak troska o własny język przybiera niekiedy karykaturalne formy. Neologizmy takie, jak drótposta (,poczta kablowa”, czyli e-mail) czy noteszgép („urzadzenie notesowe" - laptop), nie znalazły zastosowania w codziennym życiu, ale nadal występują czasem w bardziej oficjalnych komunikatach językowych (np. w programach telewizyjnych). Podobnymi prawami rządzi się język węgierskich ofert pracy. Tam, gdzie to możliwe w użyciu są madziaryzmy. Czasem jednak występują określenia angielskie lub zwroty złożone ze słów obcych i rodzimych. 
Dominująca rola angielszczyzny w ekonomii i informatyce sprawiła, że wiele nowych zjawisk przyjęło anglicyzmy jako swoje nazwy. Dotyczy to zwłaszcza tytulów stanowisk. Najpopularniejsze (189 ogłoszeń) są złożenia wyrazów rodzimych i tych pochodzenia obcego, np.: „Analityk działu controllingu”, „Project Manager ds. Zamówień Publicznych". Obok wyrazów angielskich, które już na stałe weszły do węgierszczyzny, pojawiają się nazwy własne, np. „programista Androida5" i słownictwo specjalistyczne, nieobecne w języku powszednim, np.:

Wiodąca na rynku firma informatyczna poszukuje osoby na stanowisko ERP MENEDŻER PRODUKTU.

Następny pod względem liczebności zbiór (93 oferty) stanowią zwroty powstałe wyłącznie ze słów obcych przystosowanych do węgierskiej pisowni i gramatyki, np.:

Globalna firma dystrybuująca znany brand poszukuje do swojej siedziby w Budapeszcie Asystenta marketingu.

Inne przykłady to m.in.: „Program Junior Menadżer - Kontroling”, ,asystent HR”, ,asystent projektu”, „Asystent laboratoryjny".

Do przedostatniej grupy (67 ofert) należą nazwy angielskie wykorzystane w nagłówkach lub w tekście ogłoszeń węgierskojęzycznych, np.:

Firma zajmująca się dystrybucją luksusowych kosmetyków i produktów do pielęgnacji urody poszukuje na stanowisko BRAND MANAGER energicznej, zorientowanej na sukces osoby z doświadczeniem zawodowym, która wprowadzi na rynek marke dermokosmetyków z prawem do wyłącznej dystrybucji w aptekach.

Wreszcie są i takie oferty (w liczbie 30), które podaja tytuł stanowiska w obu jezykach, np.: Technical Author/Technikai szövegíró („Autor tekstów technicznych”) lub w tekście używają nazw angielskich razem $\mathrm{z}$ ich tłumaczeniem na węgierski:

Nasze Europejskie Centrum Obsługi otwarte w 2009 oferuje usługi biznesowe dla Europejskiej Linii Rafinerii i Sprzedaży (Refining and Marketing) BP.

Pojawiają się w ogłoszeniach słowa, takie jak „szansa”, „gwarancja”, „uwaga”, „okazja”, które nie wnoszą do komunikatu wiele treści, ale przykuwają uwagę i wywołują pozytywne skojarzenia, np.:
Osoby mówiące po czesku/polsku, uwaga! (...) Do ich [firmy] młodzieńczego zespołu poszukujemy pełnych zapału osób z ponadprzeciętną znajomością języka czeskiego bądź polskiego.

Mlinar H S.A. gwarantuje, co następuje...

Twoje szanse rosną, jeśli...

Możliwość pracy na stałe/ okresowo dla pracowników kwalifikowanych.

Jeśli tak, to z powodzeniem możesz ubiegać się o opisaną tutaj posadę!

Atrakcyjnych słów używa się także przy opisie korzyści związanych ze stanowiskiem:

Oferujemy:

Ciagłe wspieranie pracowników w ich zawodowym i osobistym rozwoju

Możliwości międzynarodowej kariery w młodym i innowacyjnym zespole

Konkurencyjne wynagrodzenie i atrakcyjny pakiet świadczeń

Zniżki pracownicze przy zakupie produktów Bosch

Systematyczną wymianę doświadczeń z zagranicznymi placówkami

Możliwość nauki języków obcych.

\subsection{Stylistyka}

Ogłoszenie posługuje się różnymi stylami wypowiedzi, m.in.: naukowym, artystycznym, potocznym (Lubaś, 2006, s. 143$150)$. Wśród zebranych ofert wiele sięga po styl retoryczny. Przez to określenie rozumiem język wystąpień publicznych, który przekazuje informacje, ale fakty dobiera i przedstawia w sposób sprzyjający własnym celom. W ofertach często występowały takie postaci mowy, jak w poniższym przykładzie; zwroty do odbiorcy (szczególnie liczne były pytania), nagromadzenia składniowe (szczególnie pytania alternatywne), gradacja (od życzeń do wymagań), powtórzenia, metafory, synekdochy, niedomówienia itd.

Position Overview and Responsibilities [opis stanowiska i obowiązków]

Pragniesz inwestować w swoją znajomość elektrotechniki w naszej wielonarodowej firmie?

Chcesz, pracując w międzynarodowym zespole, zachować swoją niezależność?

Masz ochotę zdobyć doświadczenie zawodowe na polu elektroniki i niektórych związanych $\mathrm{z}$ nia zasad handlu (klasyfikacja towarów według międzynarodowych standardów) trzech kontynentów (Ameryki, Europy, Azji)? Nie masz problemów z pisemnym ani ustnym angielskim? U nas to podstawa...

Interesujesz sie budową oraz działaniem używanych i produkowanych przez nas urządzeń elektronicznych? 
Co sądzisz o produktach Microsoft Office? Poradzisz sobie z tabelkami Excela i dokumentami Worda?

Potrafisz pracować nad kilkoma rzeczami naraz z równą dbałością o szczegóły?

\subsection{Pragmatyka}

W prawie połowie badanych ogłoszeń węgierskojęzycznych (597) występowały presupozycje wskazujące na atrakcyjność danej firmy albo posady, np.:

Do dynamicznego zespołu grupy kapitalowej (sektor samochodowy) z siedziba w Budapeszcie poszukujemy ambitnych osób na następujące stanowisko:...

Powyższe zdanie informuje o pewnym wakacie, ale jednocześnie wskazuje, że chodzi o prace w „dynamicznym zespole”. W innym ogłoszeniu, opisując zalety posady, podano informację o silnej pozycji firmy na rynku:

Stabilne miejsce pracy w najpotężniejszej w regionie firmie piekarskiej.

Obecne były również implikatury (ok. 500 ofert, granice implikatury są płynne), np. powiazzanie osobistego sukcesu ze stroną internetową firmy:

Gdzie zaczyna się historia Twojego sukcesu? Zgłoszenia i nasze pozostałe oferty: www. bosch.hu/jobs

\subsection{Slogan}

W sloganach zazwyczaj wykorzystywane są gry językowe i inne atrakcyjne złożenia słów. Opierają się często na homonimii, np. hasło jednej $\mathrm{z}$ firm rekrutacyjnych: Emberi megoldások („Ludzkie rozwiązania”) oznaczać może zarówno rozwiązania dotyczace ludzi, jak i rozwiazania o humanitarnym charakterze. Podobnie hasło reklamowe całego serwisu Jobline.hu: Keresni is jól lehet opiera się na dwuznaczności czasownika keres, który tłumaczymy jako „poszukiwać” albo „zarabiać”, a więc. „Zarabiać też można dobrze” lub „Szukać też da się dobrze".

Kolejnym przykładem jest wykorzystanie związku frazeologicznego horogra akad („połknąć haczyk, dać się złapać”) w sloganie jednej z firm rekrutacyjnych (Horogra akar akadni? Chce (pan/i) dać się ztapać? Chce (pan/i) potknać haczyk?). Posłużono się tym zwrotem w dwójnasób. Po pierwsze dokonano jego deleksykalizacji, tzn. utarte powiedzenie o metaforycznym znaczeniu przedstawiono dosłownie, jako mężczyznę na szczudłach usiłujacego zaczepić się o hak. Po drugie negatywne skojarzenia towarzyszące temu idiomowi („dać się złapać” sugeruje pewną naiwność „ofiary”) przekuto na korzyść korporacji. „Połknąć haczyk" ma tutaj oznaczać skorzystanie z życiowej okazji, ma popychać nas do działania, zacheccać do chwycenia tej szansy.

Naszą uwagę zwracają zabawne czy zagadkowe zdarzenia i wypowiedzi. Łatwiej je też zapamiętujemy. Niektóre slogany jednak nie próbuja nas zaskakiwać ani rozśmieszać, ale starają się raczej zmotywować. Velünk első lesz! („Z nami bedzie pan/i pierwszy/a!”) czy Legyünk együtt sikeresek! („Odnieśmy sukces razem!”) sięgają po środki językowe inne niż wieloznaczność słów czy zwrotów. Oba hasła korzystają z wykrzyknienia i podkreślaja możliwość zmiany na lepsze (czas przyszły, tryb rozkazujacy) oraz siłe płynaca z solidarności ludzkiej („z nami”, „razem”). W ten sposób mają zachęcać do podjęcia działania. Co więcej w oryginale posługują się wyłącznie samogłoskami przedniego szeregu (magas hangrendü magánhanzók), które w języku węgierskim kojarzone sa z radosną tematyką (Rácz i Takács, 2011, s. 61-64), podobnie jak tonacja majorowa w muzyce. Korzystanie z głosek przednich ma nas pozytywnie nastawić wobec komunikatu.

O ile zdarza się, że korporacje zamieszczajace ogłoszenia własne, poszukujace pracowników na własne potrzeby, mają też własne hasła reklamowe dla swych działań rekrutacyjnych, to slogany te $\mathrm{z}$ reguły różnia sie od haseł firm HR. Zazwyczaj jest to zdanie dłuższe i bardziej rozbudowane, a przede wszystkim - zdanie, a nie równoważnik zdania. Często towarzyszy mu ogólny, tzn. nierekrutacyjny slogan firmy.

Czasem jest go pozbawione, np.:

Ugruntuj swoja przyszłość z Mercedes-Benzem!

Podobnie, jak w ofertach zamieszczanych przez firmy rekrutacyjne, również w ogłoszeniach własnych natrafiamy na użycie homonimii. Slogan pewnego węgierskiego przedsiębiorstwa energetycznego brzmi: Pani/Pana energia, nasz wspólny sukces, $\mathrm{z}$ podhasłem bedacym rozwinieciem i wyjaśnieniem powyższego: Niech Pan/i dotaczy do wiodacego dostawcy ustug energetycznych na Wegrzech! 


\section{Analiza pozajęzykowych środków perswazji}

\subsection{Marketing}

W ogłoszeniach ujawnia się preskryptywny model języka i wpływ marketingu na rynek pracy. Pojawia się metoda „tzw. małych akceptacji, a więc potwierdzeń za pomocą partykuły tak" (Pałka, 2006, s. 128). Polega na zadawaniu ciągu pytań alternatywnych, np.:

Masz doświadczenie w programowaniu Delphi? Interesujesz się branżą motoryzacyjną? Zdarzyło Ci się już projektować hardware?

Posiada Pan/i dyplom z księgowości? Zna $\mathrm{Pan} / \mathrm{i}$ angielski na poziomie średnio-zaawansowanym? Chciał/aby Pan/i pracować dla wielonarodowej korporacji?

Znasz francuski na zaawansowanym poziomie? Pragniesz rozpocząć karierę? A może masz już jakieś doświadczenie w podobnej dziedzinie?

Doskonale mówisz po angielsku ORAZ po polsku? Pracował(e/a)ś już w turystyce lub hotelarstwie? Masz doświadczenie w korzystaniu z systemu rezerwacji online (GDS)?

Chciał/aby Pan/i czuć pewny grunt pod nogami, ale w pracy napotykać na ciagłe wyzwania? Pracować w miłym środowisku w przyjaznej, małej firmie? Interesuje się Pan/i zarówno handlem, jak i finansami?

Pytajniki w takim nagromadzeniu występują wyłącznie na początku oferty (obecne w 239 ogłoszeniach) i mają stwarzać wrażenie, że dane działanie (np. wysłanie zgłoszenia) jest słuszne. Że oferowana praca w pełni nam odpowiada, skoro zgadzamy się na „warunki” przedstawione na wstępie. Że nie bez przyczyny pytania następują po sobie, bo na pewno stoja w jakimś związku logicznym. Przytaknięcie im ma sprawiać, że chcąc zachować się konsekwentnie, przystaniemy także na dalszą część ogłoszenia.

Innym tropem marketingowym obecnym w badanych ofertach jest ,przyjacielskość” (Pałka, 2006, s. 121-127) wynikająca nie z bliskich więzi emocjonalnych między ludźmi, ale $\mathrm{z}$ chęci ułatwienia procesu komunikacji. Reguły przyjacielskiej, uprzejmej konwersacji zostały zdefiniowane przez Geoffreya Leecha oraz Robina Lakoffa Ten wzorzec zachowań zakłada, że rozmowa przebiegnie przyjemniej i korzystniej dla wszystkich zainteresowanych, jeśli zastosuja się do następujących regut: nie narzucaj się (działaj taktownie), nie przejawiaj wrogości (zachowuj odpowiedni dystans), pozostawiaj wolny wybór (nie upieraj się przy swoim), nie zawłaszczaj konwersacji (pozwól się wypowiedzieć innym), unikaj różnicy zdań (utrzymuj przyjacielskie stosunki), unikaj ciszy (podtrzymuj kontakt werbalny) (Pałka, 2006, s. 121).

Przestrzeganie tych maksym ma wytworzyć atmosferę sprzyjającą perswazji, podobna do sytuacji udzielania przyjacielskiej rady. W ogłoszeniach przejawia się to m.in. w pytaniach wyrażających pozorną troskę o samopoczucie, o życiową samorealizację potencjalnych kandydatów (zdania pytajne rozpoczynające się od słów: „chciał/abyś, interesujesz się, masz ochotę" itp.) czy w formułkach grzecznościowych typu:

Jeśli powyższa oferta wzbudziła Pani/Pana zainteresowanie i sadzi Pan/i, że stanowi ona wyzwanie zawodowe, prosimy o przesłanie życiorysu ze zdjęciem i numerem oferty na poniższy adres e-mail.

Kolejną techniką reklamową są repetycje. Powtarzanie pewnych treści ma ułatwić ich zapamiętywanie. Kilkukrotne podkreślenie tych samych zalet firmy czy posady ma prowadzić do identyfikowania danej marki bądź stanowiska $\mathrm{z}$ pozytywnymi cechami.

Często stosuje się powtórzenia w obrębie pojedynczych ogłoszeń, np. umieszczenie dwóch bardzo podobnych rubryk jedna po drugiej:

Czekamy na zgłoszenia od osób, dla których liczy się:

Osobisty rozwój, samorealizacja

Tworzenie własnej przyszłości

Bezstresowa praca

Błyskawiczna kariera, szybki awans na stanowisko kierownicze

Sprostanie wyzwaniom

Samodzielność, kreatywność

Pomaganie innym

Nie boją się ciężkiej pracy, ale chca wysokich zarobków

Praca zespołowa

Ciagła nauka, ale jednorazowy jej koszt

Naszym celem jest znalezienie osób, które:

Mają ambitne cele życiowe

Dla których liczy się odpowiedzialne partnerstwo i humanizm

Poszukują wyzwań i pragną im sprostać Chca aktywnie brać udział w bieżących przemianach gospodarczych

Chcą służyć pomocą różnym warstwom społeczeństwa

Pragną zwiedzić z nami świat i żyć na poziomie wyższym od przeciętnego. 
Lub też zamieszcza te same treści w więcej niż jednym ogłoszeniu. Poniższy fragment pojawił się w ponad 20 ofertach pracy:

„Made by Bosch" to synonim doskonałej jakości. Nasza znana i na całym świecie uznana firma poprzez rozwój zintegrowanych systemów szuka innowacyjnych rozwiazań w auto-elektronice. W swoim centrum badań i rozwoju w Budapeszcie (...), działając w międzynarodowym środowisku, od $2001 \mathrm{r}$. ulepszamy na potrzeby branży motoryzacyjnej elementy sterujace. Nasz dynamicznie rosnący w siłę zespół stale poszukuje wykwalifikowanych specjalistów.

Ostatnim elementem, na który chciałabym zwrócić uwagę, jest podkreślenie marki poprzez podanie jej nazwy na początku i na końcu oferty. Ponoć najlepiej zapamiętujemy informacje zawarte we wstępie i zakończeniu komunikatu, a środek zazwyczaj łatwiej nam umyka. Właściwość te wykorzystuje się zarówno w reklamie, jak i w badanych ogłoszeniach. Taki zabieg obecny był we wszystkich ofertach firm HR oraz w ogłoszeniach większości korporacji międzynarodowych i u niektórych przedsiębiorstw węgierskich.

\subsection{Odwołania do świata spoza ogłoszenia}

Najczęściej występującym (624 oferty) majacym zachęcić do podjęcia współpracy $\mathrm{z}$ daną firmą odwołaniem jest wskazanie potencjalnych korzyści związanych z proponowanym stanowiskiem. Wśród zalet posady podawano przede wszystkim:

- atrakcyjność miejsca pracy (558 ofert), np.: dynamiczny zespół; nowoczesne, młodzieńcze otoczenie; innowacyjne, wysokiej jakości miejsce pracy; międzynarodowe środowisko; firma o stabilnych, solidnych podstawach;

- możliwości rozwoju (582 oferty), m.in.: wsparcie i pomoc w rozwoju; ciągłe podnoszenie kompetencji zawodowych; możliwość nauki języków obcych;

- profity finansowe (477 ofert) i to zarówno te związane bezpośrednio $\mathrm{z}$ wypłatą (np.: konkurencyjne wynagrodzenie; stała pensja + prowizja od sprzedaży; dodatek na Boże Narodzenie, 13. pensja; zarobki oparte na wynikach), jak i inne, niemożliwe do spienięzenia korzyści (m.in.: stołówka; możliwość zakupu produktów ze zniżka; firmowy samochód, telefon i laptop; bezpłatna nauka języków; pomoc w wynajmie mieszkania); konkretne sumy padały bardzo rzadko;
- ścieżkę kariery (355 ofert), np.: kariera kierownicza; możliwość awansu wewnątrz firmy;

- warunki zatrudnienia, np.: zatrudnienie od zaraz; stabilne miejsce stałej pracy; zatrudnienie na pełen etat; elastyczny czas pracy.

Inne odwołania mające zwiększyć zainteresowanie odbiorców to zwroty do konkretnych grup pracowniczych (115 ofert). Wśród nich najczęstsze (w liczbie 66) były te kierowane również do osób dopiero rozpoczynających karierę zawodową (pályakezdók), np.

...do naszego zakładu poszukujemy osób $\mathrm{z}$ doświadczeniem lub bez na następujące stanowisko..

Pozostałe odniesienia dotyczyły cech związanych z fizycznością kandydujących. Tutaj przeważały (43 oferty) zwroty do osób $\mathrm{z}$ orzeczeniem o niepełnosprawności, np.:

Czekamy również na zgłoszenia osób częściowo niezdolnych do pracy.

Sporadycznie występowały ogłoszenia (zaledwie 5) podkreślające dostępność danej posady dla obu płci, np.:

Uwagi: Czekamy na zgłoszenia zarówno kobiet, jak i mężczyzn!

W tym jedno skierowane raczej do kobiet (nie było takich ofert dla mężczyzn):

Stanowisko biznesowe również dla przyszłych mam.

Jedna tylko oferta zawierała odniesienie do wieku zainteresowanych:

Czekamy na zgłoszenia: wszystkich grup wiekowych, nie wykluczamy osób bez doświadczenia.

\subsection{Oprawa graficzna}

$\mathrm{Na}$ wizualną stronę oferty składa się kilka czynników, przede wszystkim kompozycja i kolorystyka. W świecie reklamy dominują barwy żywe, jasne, nasycone, ale nie nazbyt jaskrawe. Unika się kolorów przygnębiajaccych lub wywołujących negatywne skojarzenia, jak fioletowy czy czarny (Szczęsna, 2003, s. 34), choć oczywiście konotacje i symbolika kolorów są różne w poszczególnych kulturach. Większość ofert prezentuje tekst w naturalny, neutralny sposób: czarne litery na białym tle. Istotne elementy, takie jak nazwa firmy, stanowiska czy nagłówek, zaakcentowane są najczęściej niebieską lub czer- 
woną czcionką. Czasami pojawiają się inne wyróżnienia w tekście, np. podkreślenie czy pogrubienie liter.

Gros ofert (1546) opatrzono graficznym znakiem firmowym (logo), wiele z nich (1171 ogłoszeń) dodatkowo uatrakcyjniono ilustracją. Są to w większości zdjęcia (w przypadku jednej firmy rekrutacyjnej i jej 33 ogłoszeń - rysunek) przedstawiające ludzi (1153 oferty) lub samochody (18 ofert). Pojawiają się prawie wyłącznie na początku ogłoszenia i mają za zadanie przykuć naszą uwagę. Zdjęcia ukazują zadbane, nowoczesne auta bądź młode, atrakcyjne osoby: uśmiechnięte, zdrowe, energiczne, elegancko i schludnie ubrane, zazwyczaj o jasnej cerze i ciemnych włosach. Takie wizerunki odwołują się do obecnych na Węgrzech wyobrażeń na temat sukcesu.

\section{Zakończenie}

Starałam się wykazać, że analizowane oferty pracy w większości można pojmować jako reklamę. Dotyczy to zarówno celów, jak i środków realizacji badanych tekstów.

Poetyka reklamy wyraża się przede wszystkim poprzez język. Poczynając od warstwy gramatycznej, poprzez leksykalną i stylistyczną, aż do pragmatycznej, język tych ogłoszeń jest narzędziem służącym nie tyle do informowania, co do zachwalania, zachęcania, zmotywowania. Język jest również wehikułem dla marketingowych i pozatekstowych (odwołujacych sie do świata poza tekstem) środków perswazji. Ponadto w ofertach pojawia się retoryka znana często z reklam (Gołka, 1994 s. 90-92), jak powoływanie się na autorytet i odwoływanie się do różnych ukrytych potrzeb (potrzeby bezpieczeństwa, próżności, tworzenia itd.).

Jednocześnie nie należy zapominać o wizualnej stronie oferty. Większości ogłoszeń towarzyszy konkretny program ikonograficzny (logo, zdjęcie, kolory budzące pozytywne skojarzenia), również mający na celu wzbudzenie $\mathrm{w}$ nas zainteresowania i korzystnego nastawienia wobec danej firmy.

Analogie dotycza nie tylko ostatecznego wyglądu ogłoszeń. Również droga do ich realizacji nasuwa na myśl skojarzenia ze światem reklamy. Przede wszystkim większość ofert została przygotowana przez firmy rekrutacyjne poszukujące pracowników w czyimś imieniu. Podobnie jak reklamy - zostały stworzone na zlecenie, odpłatnie zachwalają cudzy produkt. Co więcej, tak jak kampanie reklamowe, oferty firm rekrutacyjnych mają określone grono docelowych odbiorców.

Dotyczy to nie tylko ofert prezentowanych przez przedsiębiorstwa rekrutacyjne, ale również ogłoszeń własnych, które $\mathrm{w}$ większości tworzone są $\mathrm{w}$ podobny sposób: z wykorzystaniem retoryki reklamy.

\section{Przypisy}

1 Artykuł powstał na podstawie pracy licencjackiej napisanej pod kierunkiem dr Katalin Török i zaprezentowanej w Katedrze Hungarystyki Uniwersytetu Warszawskiego.

2 W nawiasach podaję przykłady odnoszące się do zebranych przeze mnie ofert pracy.

3 Publikacja dotyczy m.in. zastosowania teorii oczekiwań w opisie preferencji kandydatów na temat miejsca zatrudnienia.

4 Wyrugowanie z użycia wszelkich zapożyczeń było jednym z postulatów neologizmu, XIX-wiecznego ruchu literackiego na rzecz odnowy języka węgierskiego.

5 Android - nazwa systemów operacyjnych dla urządzeń mobilnych (np. smartfonów, tabletów).

6 Enterprise resource planning, czyli planowanie zasobów przedsiębiorstwa - rodzaj programów komputerowych wspomagających zarządzanie przedsiębiorstwem.

\section{Bibliografia}

Abrahams, A.S., Coupeyb, E., Zhonga, E.X., Barkhic, R., Manasantivongsd, P.S. (2013). Audience targeting by B-to-B advertisement classification: A neural network approach. Expert Systems with Applications, 40(8), 2777-2791.

Bralczyk, J. (1994). Reklama - perswazja informacji. W: E. Kisielewska (red.), Sztuka reklamy. Warszawa: Biuro Reklamy.

Bralczyk, J. (2004). Język na sprzedaż. Gdańsk: Gdańskie Wydawinctwo Psychologiczne.

Gołka, M. (1994). Świat reklamy. Puszczykowo: Agencja Badawczo-Promocyjna Artia.

Gregory, C.K., Meade, A.W., Foster Thompson, A. (2013). Understanding internet recruitment via signaling theory and the elaboration likelihood model Computers in Human Behavior, 29(5), 1949-1959.

Grzegorczykowa, R. (1990). Wprowadzenie do semantyki językoznawczej. Warszawa: PWN.

Hodes, B.S. (1982). The principles and practice of recruitment advertising: a guide for personnel professionals. New York: Frederick Fell Publishers Inc.

Jobline.hu (b.d.). Pobrano z: https://jobline.hu/.

Lewiński, P.H. (1999). Retoryka reklamy. Wrocław: Wydawnictwo Uniwersytetu Wrocławskiego. 
Lubaś, W. (2006). Język w komunikacji, w perswazji $i w$ reklamie. Dąbrowa Górnicza: Wyższa Szkoła Biznesu.

Ngai, E.W.T. (2003). Selection of web sites for online advertising using AHP. Information and Management, 40, 233-242.

Pałka, P. (2006). Perswazja w dyskursie handlowym - wpływ obcych wzorów. W: K. Ożóg i E. Oronowicz-Kida (red.), Przemiany jezyka na tle przemian wspótczesnej kultury. Rzeszów: Wydawnictwo Uniwersytetu Rzeszowskiego.

Rácz, E., Takács, E. (2011). Kis magyar nyelvtan. Borsodi Nyomda: AKKORD.

Rybiński, K. (2007). Globalizacja $w$ trzech odstonach. Część 1. Outsourcing, offshoring $i$ networking jako przyczyny pojawienia sie „homo sapiens globalus" w XXI wieku. Pobrano z: http://www. rybinski.eu/wp-content/uploads/offshoring_061027. pdf.
Rynes, S. (1991). Recruitment, job choice, and post hire consequences: A call for new research directions. W: M. Dunnettem, L. Hough (red.), Handbook of industrial and organizational psychology, wyd. II, (399-444). Palo Alto, California: Consulting Psychologists' Press.

Skowronek, K. (2001). Reklama. Studium pragmalingwistyczne. Kraków: Rabid.

Stokes, R. (2008). eMarketing: The Essential Guide to Online Marketing. Quirk eMarketing (Pty) Ltd.

Szczęsna, E. (2003). Poetyka reklamy. Warszawa: PWN.

Wołk, M. (2001). Ogłoszenie czy reklama? Problem definiowania pojęcia 'ogłoszenie'. Prace Językoznawcze Uniwersytetu Warmińsko-Mazurskiego w Olsztynie 3, 149-166.

Zusman, R.R., Landis, R.S. (2002). Applicant preferences for Web-based versus traditional job postings. Computers in Human Behavior, 18(3), 285-296. 